\title{
Under Which Constitutional Arrangement Would You Still Prefer to be Unemployed? Neoliberalism, the Peace Process, and the Politics of Class in Northern Ireland
}

\section{Colin Coulter}

To cite this article: Colin Coulter (2014) Under Which Constitutional Arrangement Would You Still Prefer to be Unemployed? Neoliberalism, the Peace Process, and the Politics of Class in Northern Ireland, Studies in Conflict \& Terrorism, 37:9, 763-776, DOI: 10.1080/1057610X.2014.931212

To link to this article: http://dx.doi.org/10.1080/1057610X.2014.931212

Accepted author version posted online: 16 Jun 2014.

Published online: 16 Jun 2014.

Submit your article to this journal $₫$

Џ Article views: 416

Q View related articles $\sqsubset$

View Crossmark data $\nearrow$

4 Citing articles: 5 View citing articles 진 


\title{
Under Which Constitutional Arrangement Would You Still Prefer to be Unemployed? Neoliberalism, the Peace Process, and the Politics of Class in Northern Ireland
}

\section{COLIN COULTER}

\author{
Department of Sociology \\ National University of Ireland, Maynooth \\ County Kildare, Ireland
}

\begin{abstract}
This article seeks to critically examine the political economy of the Northern Irish "peace process." When the principal paramilitary organizations in the region declared cease-fires in 1994, it was widely assumed that political progress would be followed by economic prosperity. However, this "peace dividend" has never fully materialized. Those working-class communities that were at the center of the Troubles have derived little economic benefit over the last two decades. Indeed, if anything the already substantial class divisions in the six counties have become more pronounced over the course of the peace process. The article concludes by suggesting that these widening socioeconomic disparities have the potential to undermine the prevailing political settlement in Northern Ireland.
\end{abstract}

In recent international debates about strategies for conflict resolution, one of the most prevalent voices has contested that it is economic-rather than political-liberalism that holds the key to progress. This faith in the palliative power of the free market has of course dominated the policies prescribed and imposed by the institutions of global political power for decades and is expressed succinctly by Gartzke when he asserts that "capitalism, and not democracy, leads to peace." The assumption that the embrace of neoliberal economics will pave the way to genuine political stability has been a central theme in mainstream discourse in relation to the "peace process" in Northern Ireland. This particular reading invariably fails to square, however, with the stubborn political and economic realities that have defined the region over the two decades since the 1994 paramilitary cease-fires. Indeed, if the Northern Irish peace process might be said to have been a success, it has been so in spite and not because of developments in the local economy. The "peace dividend" that never really materialized during the long years of global capitalist expansion is an even more distant prospect now that boom has turned to bust. The onset of worldwide economic crisis has, however, only served to strengthen the appeal of neoliberal policies among those who exercise power within and without Northern Ireland. Twenty years after

Received 14 January 2014; accepted 16 May 2014.

Address correspondence to Colin Coulter, Department of Sociology, National University of Ireland, Maynooth, County Kildare, Ireland. E-mail: colin.coulter@nuim.ie 
the original cease-fires, politicians of almost every stripe are intent on advancing a version of free market economics that will have social repercussions that may well in time invite some very fundamental questions about the nature and stability of the political settlement in Northern Ireland.

\section{Conspiracy of Hope}

The cease-fires that the principal paramilitary organizations in Northern Ireland called in the late summer and autumn of 1994 took place, it is worth remembering, at a very specific moment in the evolution of global capitalism. ${ }^{2}$ With the end of the Cold War, a wave of capital flowed out of the United States in particular in pursuit of hitherto untapped markets, generating an era of frenetic economic growth. Grizzled economists in Washington found common cause with techno-utopian hipsters in Silicon Valley in heralding the dawning of a "new economy" that would bestow unprecedented and endless prosperity across the globe. ${ }^{3}$ And for a period of almost two decades, of course, it looked like they might just be right.

The profound sense of optimism that attended most discussions of the global economy in the 1990s almost inevitably found an echo in the way in which the nascent Northern Irish peace process was framed. In official circles at least, it became axiomatic that the paramilitary cease-fires would, if sustained, prepare the ground for a period of political stability that would in turn allow Northern Ireland to attract the foreign investment that would enable the region, at long last, to enjoy sustained economic growth. The intimate association between peace and prosperity within mainstream discourse was established early on and featured heavily in a keynote speech delivered by the serving U.K. prime minister a week after the loyalist declaration that they had followed republicans in ending military operations. On 21 October 1994, John Major reflected on the significance of recent events at a gathering in Belfast of the Institute of Directors. ${ }^{4}$ The advent of the ceasefires had, the Conservative leader suggested, created the conditions of the possibility of a virtuous circle in which political progress and economic advancement would become mutually reinforcing: "Peace of itself will give a massive boost to Northern Ireland's economy. Equally the chance of more prosperity, more jobs, better security for families must be the most powerful incentive for peace."

The faith that the British prime minister expressed in the economic potential of political reconciliation would be shared by his successor but rendered in a decidedly more evangelical tone. In May 1998, Tony Blair arrived in Belfast seeking to persuade wavering voters to lend their support in the forthcoming referendum that would determine the fate of the principal piece of architecture within the Northern Irish "peace process." Addressing the annual Royal Agricultural Show, the Labour premier issued an impassioned appeal on behalf of the Belfast Agreement, contesting that those who cast a vote in favor of the deal struck between most of the local parties would in effect entail saying "yes to hope, to peace, to stability, and to prosperity." A ringing endorsement of the new political dispensation would, Blair insisted, signal a "peaceful and stable future" in which Northern Ireland would come to enjoy the favor and regenerative power of multinational capital: "I have no doubt that there is a well of economic goodwill and potential inward investment out there just waiting for the right opportunity and the right conditions. Let us turn that prospect into a reality."

The optimistic and, at times, messianic tone that defined Tony Blair's approach to the Northern Irish peace process would find an analog of course in the disposition of his fellow traveler on the "Third Way," Bill Clinton. In November 1995, barely a year after the original paramilitary cease-fires, the U.S. president became the first incumbent of that 
office to pay an official visit to Northern Ireland. Speaking to a gathering in the East Belfast Enterprise Park, ${ }^{6}$ Clinton claimed to discern the first signs of the economic benefits flowing from political progress and went on to express his hope that the "entrepreneurs" ranged before him would come to provide "a model for a lot of other countries as well who are struggling to build a system of free enterprise." In his two subsequent trips to Northern Ireland, the U.S. president was at pains to underline that this initial estimation was increasingly being borne out by a range of economic data. During his last visit to the region before leaving office, Clinton addressed a vast audience at the Odyssey Arena and employed that venue-hallmark of the "regeneration" of much of inner Belfast now designated as "Laganside" - as a convenient metaphor of what was understood as the rather broader economic renaissance of the region. ${ }^{7}$

The various occasions on which Bill Clinton came to Northern Ireland all coincided, it is worth marking, with a prolonged period of global economic boom that had conferred at least some benefit on the region. As a consequence, the irrepressible optimism of the U.S. president did not, to most eyes at least, appear out of kilter with the prevailing order of things. By the time another Democrat living in the White House would pass through Northern Ireland, however, the global economic environment would have altered dramatically. In June 2013, Barack Obama stopped off in Belfast en route to the G8 Summit convened in the idyllic environs of County Fermanagh. In the plush Waterfront Hall located in the city center, the U.S. president engaged a crowd composed almost entirely of young people. While the occasion took place against a backdrop of world economic crisis on a scale not seen for several generations, Obama delivered an address that sought to puncture the pervasive gloom of the new age of austerity. ${ }^{8}$ The U.S. president stated that the peace process represented a "courageous path" that had generated the "social and economic benefits" that have allowed the creation of a "thoroughly modern Northern Ireland." His speechwriters, as one would expect, had evidently done their homework, adding a little local flavor to the text that chimed successfully with the autobiographical detail of an audience that was clearly hanging on every word:

... Belfast is a different city. Once-abandoned factories are rebuilt. Former industrial sites are reborn. Visitors come from all over to see an exhibit at the MAC, ${ }^{9}$ a play at the Lyric, a concert here at Waterfront Hall. Families crowd into pubs in the Cathedral Quarter to hear "trad." Students lounge at cafés, asking each other, "What's the craic?" (Laughter and applause).

While the incidental detail that garnishes the speech is certainly rather telling, it is especially so in a way that the Obama team could not possibly have intended. The various venues and practices mentioned in the text are already familiar from a host of glossy commercials that seek to construct the Northern Irish capital as a newly fashionable place that is "ready to party." 10 These representations of the "new Belfast" weave a narrative that is at best, however, only partially true. While the MAC and the Waterfront may well be cherished sites of consumption and edification for some, they exist beyond the financial resources and cultural compass of many less affluent residents of the city. These venues might be read, therefore, not only as emblems of the benefits that have flowed from the peace process but also of the lack of real progress that has, in certain respects, occurred over its course. When the main republican and loyalist paramilitaries decided to lay down their arms back in 1994, Northern Ireland was a society deeply scarred by poverty and inequality. The passage of 
two decades - as the discussion that follows will illustrate-has, alas, done rather little to alter that particular, miserable reality.

\section{The Political Economy of Peace}

The principal political figures that sought to secure and advance the peace process in Northern Ireland drew heavily, as we have seen, on the assumption that political progress would usher in an era of unparalleled opportunity and prosperity. While there is some evidence that a "peace dividend" has materialized in the region, its benefits have, however, been neither universal nor evenly distributed. The single most recurrent pledge that informed official discourse on the peace process was that if paramilitary organizations were to maintain their cease-fires, there would be an influx of multinational capital, especially from the United States, that would lift Northern Ireland out of its seemingly perennial condition of underdevelopment. In the immediate aftermath of the cease-fires, it appeared that the agencies of global capital might well make good on that particular bold promise. Between 1994 and 2000 , almost $\$ 1.5$ billion was invested in Northern Ireland by American multinationals alone, accelerating an already existing downward trend in the unemployment rate in the region. ${ }^{11}$ This initial wave of foreign direct investment would not, however, be sustained beyond the turn of the century. The statutory body established to induce multinationals to set up business in Northern Ireland has performed quite astonishingly poorly since its creation in 2002. According to the investigative journalist Niall McCracken, ${ }^{12}$ the almost $£ 1$ billion spent by Invest NI in the first five years of its existence alone led-if job losses, as well as gains, in sponsored companies are factored in - to the creation, on balance, of a mere 328 stable positions. It would seem that the "well of economic goodwill" toward Northern Ireland that Tony Blair believed to exist on the eve of referendum on the Belfast Agreement has all but evaporated.

In spite of the seeming indifference of multinational capital to the investment potential of Northern Ireland, the region did nonetheless experience something of an economic revival at the outset of the new century. This period of apparent growth owed its origins principally to a property boom that saw house prices in the six counties rise from their traditional status as the lowest in the United Kingdom to the highest outside of London and the south east of England. Employment opportunities in construction in particular expanded rapidly and by the middle of the 2000s one in five Northern Irish men who had a job worked in this sector. ${ }^{13}$ The acceleration of house prices in the six counties was of course widely interpreted in political and media circles as both emblem and agent of a renewed economic vitality in the region. As O'Hearn ${ }^{14}$ noted at the time, however, the various activities associated with the property business were unlikely to provide a sustainable basis for real economic development over time and so it was to prove. The especially steep rise in house prices that happened in Northern Ireland over a short, frenzied period in the mid-2000s meant that when the property bubble burst internationally the impact was particularly dramatic in the six counties. In the spring of 2013, it was estimated that one third of Northern Irish households were trapped in "negative equity." 15 One of the principal legacies, therefore, of the supposed boom years of the peace process is widespread private debt on a scale that would have been simply unimaginable in the era when the conflict still raged.

Although the record of Northern Ireland in terms of attracting multinational investment has been weak across the board, it has proved especially poor in high wage, high value added occupational sectors. According to Nolan, ${ }^{16}$ around 60 percent of the jobs that Invest $N I$ has brought to the region are in "call centers" and two thirds of these offer wages less than the median for the private sector in general. The attraction of this particular form of 
multinational investment to Northern Ireland both reflects and compounds its status as a low wage economy. Although the universalist ethos of the public sector ensures that state employees in the six counties earn the same as their counterparts elsewhere in the United Kingdom-outside London at least—-the picture is very different in the private sector where wages are currently running at 17 percent below the U.K. average. ${ }^{17}$ A further troubling trend is the growing body of Northern Irish workers concentrated at the lower end of the earnings ladder. According to the Joseph Rowntree Foundation, the number of people in the region earning less than $£ 7.50$ per hour rose from 170,000 to 195,000 in the decade to 2011. ${ }^{18}$

One of the ostensibly progressive developments that marked the period since the ceasefires was that Northern Ireland lost its previously enduring status as the U.K. region with the highest level of unemployment. The convergence of the region toward the state wide average in this respect might, however, prove to be rather more apparent than real. There are a number of facets of Northern Irish society - not least the higher propensity of school leavers to enter higher education - that serve to deflate somewhat the official estimate of the unemployed in the six counties. If we shift our focus from "unemployment" toward "worklessness" we arrive at a rather different perspective on the state of the Northern Irish labor market. At present, one third of people aged 16 to 64 in the six counties are out of work, a rate running well above the U.K. average and exceeded solely by the North East of England. ${ }^{19}$ In view of the comparatively high levels of worklessness in Northern Ireland, it hardly comes as a surprise that the residents of the region are especially reliant on social welfare provision. Official statistics reveal that in 2011 some 23 percent of people of working age in the six counties were in receipt of at least one key welfare benefit, compared to 15 percent in the rest of the United Kingdom. ${ }^{20}$

Over the last two decades, therefore, Northern Ireland has followed a course that has diverged sharply from the one originally envisaged for the region by powerful players in London and Washington. Those optimistic forecasts of imminent economic prosperity appear distinctly ill judged when gauged against the stark realities of a society in which a great many people have difficulties finding work, are likely to be poorly paid if they do and are heavily dependent on the state to underwrite their existence as a result. If there can be said to have been a real "peace dividend" in Northern Ireland it has accrued not to the poorest sections of society in the six counties but rather to those that already enjoyed considerable privilege. The quarter century of frenetic capitalist expansion that drew to a close when the global economy convulsed into recession in the autumn of 2008 both sharpened yet further the already substantial material divisions within societies and produced an unprecedented concentration of wealth in the hands of a new global elite. The operation of these processes is as evident in the context of Northern Ireland as it is in most other societies. While most people in the region have seen their incomes stagnate or even decline in recent years, the earnings of those at the top of the occupational hierarchy have increased steadily. Almost half of the income increases that have happened over the last decade have fallen to the most affluent fifth of Northern Irish society. As a consequence, the profound material divisions in Northern Irish society have grown starker, with the most recent statistics revealing that the wealthiest fifth of households enjoy incomes 4.9 times greater than the poorest fifth. ${ }^{21}$

Within the broad swathe of the "contented classes" at the top of the socioeconomic hierarchy, there exists in Northern Ireland, as elsewhere, a small body of individuals in possession of quite staggering levels of personal wealth. According to The Guardian, ${ }^{22}$ Belfast has, in per capita terms, more people worth in excess of $\$ 30$ million than any U.K. city other than London and Aberdeen. In 2011, the Northern Irish capital was home to no fewer than 96 of these "multimillionaires." It would be hard to think of a statistic that 
highlights more vividly the profound material inequities that have survived all the many, often progressive, changes that have occurred in Northern Ireland over the last generation. While the residents of west Belfast, for instance, suffered more than most during the Troubles, they have gained very little in economic terms since the conflict effectively ended. ${ }^{23}$ Indeed, there were more state sponsored jobs located in the constituency prior to the cease-fires than there are today, which goes some way to explaining its status as the second most impoverished community in the entire United Kingdom. ${ }^{24}$ The "peace dividend" evidently has materialized elsewhere and the data on Northern Ireland's multimillionaires gives us a broad hint as to where to look. While the leafy avenues of south-and, to a lesser extent, east-Belfast may well have been largely sheltered from the carnage of the Troubles, it would seem that it is here that those who have made the greatest financial gains since the cease-fires reside. In fact, there would appear to be literally dozens of individuals settled in these exclusive parts of the city whose distance from the lives of those who clean their homes, tend their gardens, mind their children is sufficiently great that it has to be measured in tens of millions in various hard currencies.

\section{"The World of the Last Three Decades Is Gone"25}

The evidence would seem to suggest, then, that advent of the peace process never did in fact bring to pass that era of economic prosperity that a host of powerful political figures as good as promised. If the goal of building a wealthier and perhaps even fairer society proved elusive throughout the long years of global economic expansion, that task will inevitably prove even more difficult now that boom has turned to bust. The 1970s witnessed the rise of a philosophical and political enterprise that is conventionally designated as "neoliberalism." Ostensibly, the neoliberal project centered on the conviction that the unfettered operation of the free market would afford the optimal number of individuals the optimal amount of personal wealth and liberty. In practice, the objectives of neoliberalism were, as David Harvey ${ }^{26}$ asserts, rather less concerned with the advancement of the individual than with the restoration of a certain version of class power. What distinguished the neoliberal era most from previous renditions of capitalism was its drive toward the "financialization of everything." ${ }^{27}$ For a couple of decades at least, the free movement of money and the creation of secondary financial markets appeared to have allowed capital to escape its own limits. As the century turned, the neoliberal revolution had managed not only to generate the actuality of untold wealth for a small though enlarged global elite but also to create, not least through the provision of cheap credit, the illusion of previously unthinkable wealth for a whole swathe of ordinary people throughout the Western world. ${ }^{28}$ The optimism of the age was palpable and pervasive. Readers of the technoutopian bible Wired were instructed in July 1997 to ready themselves for the "long boom" of " 25 years of prosperity, freedom and a better environment for the whole world." ${ }^{29}$ Nobel Laureate Robert Lucas informed the 2003 annual gathering of the American Economics Association, apparently with a straight face, that "the central problem of depression-prevention has been solved" and that the possibility of boom turning to bust, therefore, simply no longer existed. ${ }^{30}$ Events would of course soon conspire to ruthlessly expose the hubris that often passed for economic thought in the golden age of neoliberalism.

In the autumn of 2008, Lehman Brothers became the largest corporation ever to go bust in the United States, sparking a sequence of bankruptcies that would swiftly aggregate as the biggest crisis of capitalism since the 1930s. Unnerved by the prospect of further implosions in pivotal financial institutions, many Western governments decided to bail out the banks and in so doing socialized enormous debts that had originated in private speculation. 
The onset of the global financial crisis appeared to have discredited the very ideas upon which neoliberalism was constructed. ${ }^{31}$ In a stroke, the bank bailouts in countries like the United Kingdom and the Republic of Ireland punctured the central neoliberal nostrums that corporations know better than governments how to run economies and that the state should, therefore, refrain from all intervention in the free working of the market. Although the onset of the current global slump may well have represented an intellectual crisis for neoliberalism it has not, however, transpired ultimately to be a political crisis. Indeed, as Colin Crouch ${ }^{32}$ has observed with understandable incredulity, the neoliberal project appears to have emerged from the chaos that it caused "more politically powerful than ever."

The version of neoliberalism that currently exists is radically different, however, to that which assumed hegemonic status before the fall of Lehman Brothers. The brash optimism of yesteryear has been replaced by a "glum pessimism," 33 the previous rhetoric of prosperity and play giving way to the counsel of austerity and discipline. While the form that neoliberalism takes may have altered, its substance remains essentially the same. The fundamental ambition of those who continue to advance the neoliberal project is to effect a change in the balance of social forces so as to recreate conditions conducive to profit. This imperative articulates itself most crucially in moves to dismantle what remains of the postwar social democratic consensus that neoliberalism originally set out to displace. Since the onset of the current global crisis, citizens in a range of Western societies have endured the erosion of critical forms of public provision. While the assault on the social that is the "austerity" agenda is invariably depicted as an unpalatable necessity ${ }^{34}$-"there is no alternative" - that will, in time, prove to have served the collective good, the reality is that it primarily serves a rather narrow set of interests. The erosion of the welfare state and the slashing of public sector pay may bring untold misery to a multitude of people, ${ }^{35}$ but such measures offer capital the enticing prospect of a more disciplined workforce willing to work for less as well as the possibility of yet further reductions in taxes on profit. A great many criticisms may have been leveled at the agencies of global capitalism since the onset of the current recession, but it certainly cannot be said that they would ever allow a good crisis to go to waste.

The particular strategies that are the hallmark of this cannily revised and resurgent neoliberalism find clear expression in the context of Northern Ireland. While the Northern Irish experience evidently chimes with that of other countries in the throes of recession, it also has certain specificities that are worth noting here. The first arises out of the very particular political economy forged in the six counties out of more than four decades of conflict and conflict transformation. When the original incarnation of neoliberalism was in the ascendant in the 1980s, Northern Ireland was largely sheltered from the dramatic erosion of public provision experienced in other regions of the United Kingdom. The British government concluded, reasonably, that the fragility of Northern Ireland's economy, coupled with the volatility of its political culture, rendered the six counties ill suited to the curative powers of the Thatcher revolution. Accordingly, the region continued to enjoy levels of state expenditure and employment running well above the U.K. average. ${ }^{36}$ It was in this context that the Secretary of State for Northern Ireland, Jim Prior-on the "wet" or moderate wing of the party, admittedly, but a Conservative nonetheless-was moved to observe that "we are all Keynesians here." 37

The welfarist ethos of public provision in Northern Ireland would largely survive almost two decades of Tory rule and it would not be until a Labour prime minister assumed power that the transition toward neoliberal policies would gather pace. The Blairite conviction that the institutions of the state would be transformed through exposure to the ethos and imperatives of the private sector was pursued rather less aggressively in a Northern 
Irish context but did in time begin to shape official strategy in the region. ${ }^{38}$ In 2003 , for instance, New Labour created the Strategic Investment Board with the remit of involving private corporations in the financing and completion of major infrastructural projects. These collaborations between the state and corporate sector have become increasingly common in the construction of public facilities in Northern Ireland. By 2013, there were no fewer than thirty-seven Public Private Partnerships (PPPs) operating in the region on projects with a total budget in excess of $£ 1$ billion. ${ }^{39}$

While the corporatist dogma that was the hallmark of New Labour certainly made its way to Northern Ireland, the region was nonetheless relatively insulated from the neoliberal practices that became so prevalent elsewhere. The state may well have been rolled back a generation ago in other parts of the United Kingdom, but it is still the absolute fulcrum of the Northern Irish economy. The proportion of the workforce employed in the public sector (30 percent) runs rather higher than the U.K. average ( 21 percent), while two thirds of all economic activity originates in public expenditure. ${ }^{40}$ In addition, the long running and substantial subsidy from the British Exchequer might be said to hold the very fabric of Northern Irish society together. In 2012, this "subvention" amounted to $£ 10.5$ billion, almost half of the total public expenditure of $£ 23.2$ billion in the six counties. ${ }^{41}$

The very specific political economy of Northern Ireland renders the region especially vulnerable to the new age of austerity. The Conservative and Liberal Democrat coalition at Westminster has already implemented enormous cuts in public spending and even more radical ones are in train. Given the heavy reliance of Northern Ireland on state expenditure, the probability is that the austerity measures introduced by the British chancellor will impact with particular severity in the six counties. In more specific terms, the high incidence of Northern Irish people claiming state benefits will mean that the erosion of welfare provision will have especially grave repercussions in the region. ${ }^{42}$ The advent of austerity has had catastrophic consequences even in societies that have long since been exposed to the practices of neoliberalism. In a place like Northern Ireland that hitherto has been largely shielded from the neoliberal project on the grounds of political necessity and expediency, however, the new dispensation will have even graver impact, assuming the guise of something closer to shock therapy.

The second specificity that we might choose to underscore here acknowledges that the onset of the global financial crisis coincided with fundamental changes in the governance of Northern Ireland. With some inevitability, the experiment in consociational devolution envisaged in the Belfast Agreement proved to be even more difficult to realize than originally assumed, with no fewer than four different attempts at power sharing ending in failure. It was not until 2007 that a relatively stable devolved administration was established, hinging on an historic collaboration between the Democratic Unionist Party (DUP) and Sinn Féin that would have been entirely unthinkable not long before. The formation of an executive dominated by these two previously implacable foes has facilitated the devolution of an escalating range of powers to Stormont. As a result, for the first time in four decades, many of the key decisions that affect the lives of Northern Irish people are now being taken by politicians who can actually be held to electoral account. This bold experiment in sharing power between parties previously deemed "extremists" has, inevitably, run into a series of difficulties and there are growing fears that it might even run aground entirely. The DUP and Sinn Féin often seem unable to forge a common vision for Northern Ireland and have increasingly bickered on those issues such as flags and contentious parades whose resolution is central to the prospect of a "shared future" for the six counties. ${ }^{43}$ As Brian Kelly ${ }^{44}$ has observed, however, while the senior parties in the Stormont executive are "constantly falling out" over matters of ethno-national rights and identities, on matters of social and economic 
policy they have become increasingly "ecumenical" in their "collective worship of the free market."

Over the comparatively short course of its existence, the strategy of the Northern Ireland executive has become ever more explicitly neoliberal. The mainstream parties within the Unionist tradition have conventionally leaned toward the Right of the political spectrum and hence their embrace of the doctrines of the free market was always entirely inevitable. Rather more surprising has been the increasingly marked neoliberal turn within Sinn Féin. The republican movement has traditionally cast itself as socialist, with the manifestoes of its political wing typically emphasizing the causes of equality and public provision. Since entering power, however, Sinn Féin has largely dispensed with radical rhetoric, on social and economic matters at least, and has come to embrace some key elements of the neoliberal agenda. ${ }^{45}$ The ideological convergence within the Northern Ireland executive becomes most readily apparent in the context of corporation tax.

Both Sinn Féin and the DUP are now vociferous supporters of reducing the taxes that companies in the six counties pay on their profits from the current U.K.- wide rate of 23 percent to 12.5 percent, thereby bringing it into line with the Irish Republic. Both parties hold to the view that a more generous fiscal regime would entice investment from multinationals whose capital and expertise would swiftly transform the fortunes of the Northern Irish economy. The assumption that would seem to be at work here-very explicitly so in the case of Sinn Féin but expressed sotto voce among their Unionist counterparts-is that if corporation tax were to be set at the right level, "Northern Ireland plc" ${ }^{\text {46 }}$ might be able to mimic the enormous success of the Irish Republic in attracting foreign direct investment, a success that from the early 1990s produced a decade and a half of astounding economic growth. ${ }^{47}$ The glaring problem with this argument is of course that time has moved on and the principal conditions that once engendered "the Celtic Tiger" have all but disappeared. In the early 1990s, the Irish Republic was able to tap into an unprecedented flow of global capital by positioning itself as a highly educated but relatively low waged economy that offered a gateway to a European Union whose boundaries had yet to enlarge. Two decades later, the economic context in Europe and indeed beyond looks entirely different. It is hard to see how Northern Ireland can possibly even begin to repeat the success of the Celtic Tiger when it is seeking to draw from a stream of multinational investment vastly diminished since the onset of the financial crisis and competing against economies in an enlarged Europe able to offer vastly lower wage rates and, even if the wishes of the Stormont executive were to be fulfilled, in some cases vastly lower rates of corporation tax. The proposed fiscal regime would of course draw some new investment - not least from multinational corporations seeking to reframe Northern Ireland as a tax haven from which to engage in the creative accountancy of "transfer pricing"- but the balance of probability suggests that this would never be enough to plug the attendant void in the public purse. It is estimated that in the first instance the cutting of corporation tax would reduce the budget of the Stormont executive by a sum of around $£ 400$ million every year. ${ }^{48}$ This hole in the public finances would inevitably lead to further austerity measures in a region already reeling from the $£ 813$ million taken out of public services between 2009 and $2011 .^{49}$ While various stripes of speculative capitalists would make a killing from declaring in Northern Ireland profits arising out of activity in fact often conducted elsewhere, the poorest sections of society in the region would be forced to endure yet further hardship. It would seem then that the single big idea to have enthused the Stormont executive-what O'Hearn has called the "magic bullet" of slashing corporation tax ${ }^{50}$ —holds out the prospect only of compounding the poverty and inequality that already blight the region. 
The policy options available to the parties of government in Northern Ireland in a time of global crisis are clearly narrow and hold all manner of perils, for them and indeed almost everyone else. These dangers are perhaps especially acute in the case of the mainstream republican movement. It must, for instance, be rather difficult for those who remember fondly a time when the leaders of Sinn Féin cast themselves as agents of global revolution to come to terms with a new reality in which the party hierarchy offer themselves as handmaidens of global capital. The republican leadership has sought to deflect criticism over its conversion to the cause of reducing corporation tax by framing the move as part of a wider strategy for creating an integrated all Ireland economy. The appeal of such a strategy has, however, been rather diminished by real events in the world of actually existing capitalism. Whatever attraction the idea of unifying corporation tax rates as a bridge to economic integration between the two Irelands may have had previously has largely evaporated with the demise of the Celtic Tiger. ${ }^{51}$ It is hard to imagine that even the most ardent republican finds the case for a single economy on the island especially convincing now that the former "poster child of globalization" has become of the "poster child' for debt-stricken Europe." 52

The republican fig leaves that the Sinn Féin leadership has sought to place over what are, at heart, simply neoliberal policies will, perhaps, over time fail to distract attention from their true nature. In government, republicans have already had to make some deeply unpalatable decisions and in the future will have to make many more. The sections of Northern Irish society that have been, and will continue to be, particularly badly affected by the neoliberal agenda are disproportionately those that support Sinn Féin. The vicious cuts to the welfare budget will impact particularly gravely on the party's traditional heartland in the Catholic working class, while moves to reduce and privatize the public service will disadvantage those middle-class Catholics, often working for the state, who have begun voting for Sinn Féin in more recent years. ${ }^{53}$ There will of course be attempts to suggest that the British Treasury is ultimately responsible for the escalating austerity measures. But these will convince less and less as the inescapable reality takes hold that the decisions that are damaging ordinary republicans are, as a matter of fact, being taken by other republicans.

In the main, Sinn Féin has been remarkably successfully in marginalizing the various oppositional voices that regard participation in the peace process as a betrayal of republican principles. ${ }^{54}$ Its recent conversion to an explicitly neoliberal agenda, however, may well make the party vulnerable to rather less traditional form of dissent. If Sinn Féin ministers were to implement or endorse ever more severe austerity measures, it would mean that republicans were not only administering British rule in Northern Ireland but also doing so in a manner that was most injurious to their own traditional support base. As realization of this neoliberal turn became ever more acute, growing disaffection might nurture new lines of divisions within the constituency that Sinn Féin represents, threatening the hegemony among republicans of a party whose ascendancy has been central to the entire narrative of the Northern Irish peace process. In that moment, perhaps, the space might begin to open up for an entirely different set of political priorities. Whether such a development would advance the cause of political progress in the six counties remains, of course, open to speculation.

\section{"The Biggest Trick the Devil Ever Pulled"}

The discussion that has been advanced in this article leads us inexorably toward a single very simple conclusion, namely that Northern Ireland bears all the iniquities that are the hallmark of a class-based society. While the evidence to validate this proposition appears 
overwhelming, many observers of Northern Irish life remain seemingly oblivious to the critical role that social class plays in the region. The silence that attends this aversion might be taken as the measure of the success of a certain ideological enterprise that has been a central concern of this article. In the spellbindingly byzantine Hollywood whodunit The Usual Suspects, there is a remarkable scene in which, in the midst of a police interview, the central character, Roger"Verbal"Kint, ruminates on the existence or otherwise of his own demonic alter ego Keyser Söze before channeling Baudelaire to offer the following indelible insight: "The greatest trick the devil ever pulled was convincing the world he didn't exist." 55 That particular epigram calls itself to mind when considering the essentially hegemonic status that neoliberalism has sustained more or less over the last three decades. As David Harvey has illustrated, a central objective of the neoliberal project from the outset was to cast social class as "a meaningless or at least long defunct category." 56 As national and global disparities in wealth and income grew to previously unimaginable heights, commentators dispensed with the small matter of overwhelming empirical fact to declare the "death of class." 57

The persuasive power of this particular neoliberal axiom becomes immediately apparent when we consider the dominant academic accounts of social and political life in Northern Ireland over the last two decades. At the outset of the peace process, the political scientists John McGarry and Brendan O'Leary ${ }^{58}$ published an influential text in which they returned with a frequency that suggested unhealthy preoccupation to attack materialist analyses of the conflict in the six counties. Almost two decades on, this dismissal of class-based analysis remains akin to a doxa ${ }^{59}$ in academic accounts of political subjectivity in Northern Ireland. Even the recent resurgence of interest in the issue of social class among British academics ${ }^{60}$ appears to have persuaded few scholars of the value of approaching Northern Irish society in terms other than ethno-national identity. ${ }^{61}$

The lack of resonance that class issues have in the academic analysis of Northern Ireland has echoes, more importantly, at the level of political culture and practice. When we look more closely at the way in which Northern Irish society is structured, it becomes readily apparent that the fundamental line of material fissure in the region is, now more than ever, that marked by social class. Those working-class nationalists, for instance, who endure grinding poverty do so not because they are nationalists but because they are working class. It is peculiar then to discover that class issues barely seem to impact upon the political culture of Northern Ireland. Political discourse in the region continues to gravitate around attitudes to Irish unification, a prospect that, if opinion polls ${ }^{62}$ are to be believed, exerts less appeal within the nationalist community than often assumed. When the Troubles were at their height, the satirical cartoonist Martyn Turner sought to capture what he evidently understood to be the absurd imperatives that dominate Northern Irish political life. The image in question features a social researcher, clipboard in hand, canvassing opinion in a poor urban neighborhood and quizzing a local man with time on his hands with the immortal inquiry: "Under which constitutional arrangement would you prefer to be unemployed?" The look of utter bewilderment on the jobless respondent's face represents the entirely reasonable response of someone confronted with the peculiarity of a political culture that time and again elevates the often cultural imperatives of ethno-national sentiment over the principally material concerns of class status. ${ }^{63}$ Several decades later, it is deeply dispiriting to find just how pertinent that Martyn Turner cartoon remains. There are some grounds of course for hoping that the terms of political debate might finally begin to shift in Northern Ireland. The prospect of ever more painful austerity measures implemented by unionists and republicans alike might finally open up the space for another form of politics with a different set of priorities. Historical experience does tend to counsel, 
however, that the outcome will be otherwise. Twenty years after the optimism generated by the original paramilitary cease-fires, Northern Ireland remains mired in a political culture that increasingly seems capable only of asking ordinary people to name the constitutional arrangement under which they would like to be unemployed, underemployed, underpaid, forced to into zero hours contracts or split shifts, denied adequate child care, deprived full reproductive rights, and so on.

\section{Notes}

1. Cited in John Nagle, “'Nostrum or Palliative?' Contesting the Capitalist Peace in Violently Divided Societies," Civil Wars 12(3) (September 2010), p. 219.

2. Conor McCabe, The Double Transition: The Economic and Political Transition of Peace (Dublin: Irish Congress of Trade Unions, 2013).

3. Doug Henwood, After the New Economy: The Binge ... And the Hangover That Won't Go Away (New York: The New Press, 2005).

4. Speech available at http://www.johnmajor.co.uk/page1961.html (accessed 15 May 2013).

5. Speech available at http://cain.ulst.ac.uk/events/peace/docs/tb14598.htm (accessed 15 May 2013). 2013).

6. Speech available at http://cain.ulst.ac.uk/events/peace/docs/pres4.htm (accessed 15 May

7. Speech available at http://cain.ulst.ac.uk/events/peace/docs/bc131200.htm (accessed 15 May 2013).

8. Speech available at http://iipdigital.usembassy.gov/st/english/texttrans/2013/06/201306172 76442.html\#axzz2YAH8CMJU (accessed 23 June 2013).

9. The Metropolitan Arts Centre (MAC) is an impressive facility located in central Belfast intended to "select, create and mix up music, theatre, dance and art." Built at a cost of $£ 18$ million, the MAC was opened in the spring of 2012. See http://themaclive.com (accessed 12 June 2013).

10. Peter Shirlow, "Belfast: A Segregated City," in Colin Coulter and Michael Murray, eds., Northern Ireland After the Troubles: A Society in Transition (Manchester University Press, 2008), p. 73; Peter Shirlow and Brendan Murtagh Belfast: Segregation, Violence and the City (Manchester: Manchester University Press, 2006).

11. The Portland Trust, Economics in Peacemaking: Lessons from Northern Ireland (London: The Portland Trust, 2007), p. 23.

12. Neil McCracken, "Going to Plan? How Invest NI's Strategy is Really Working Out," The Detail 5 October 2012. Available at http://www.thedetail.tv/issues/128/invest-ni/going-to-plan-howinvest-nis-strategy-is-really-working-out (accessed 23 June 2013).

13. Denis O'Hearn, "How has Peace Changed the Northern Irish Political Economy?" Ethnopolitics 7(1) (2008), p. 106.

14. Ibid., p. 109.

15. Claire McNeilly, "35\% of Northern Ireland Households Locked into a Negative Equity Nightmare," Belfast Telegraph 15 March 2013. Available at http://www.belfasttelegraph.co.uk/news/ local-national/northern-ireland/35-of-northern-ireland-households-locked-into-a-negative-equity-nightmare-29106563.html (accessed 14 June 2013).

16. Paul Nolan, Northern Ireland Peace Monitoring Report Number Two (Belfast: Community Relations Council, 2013), p. 25.

17. Department of Finance and Personnel (Northern Ireland), Monthly Labour Market Report (June 2013), p. 15.

18. Joseph Rowntree Foundation, Monitoring Poverty and Social Exclusion in Northern Ireland 2012 (York: Joseph Rowntree Foundation, 2012), p. 22.

19. Ibid., p. 2.

20. Ibid., p. 31. 
21. Department of Social Development (Northern Ireland), Households Below Average Income Report 2010-2011 (Belfast: DSDNI, 2013).

22. John Burn-Murdoch, "UK Multi-Millionaires Mapped: Where Do the Wealthy Live?," Guardian 13 September 2012. Available at http://www.guardian.co.uk/news/datablog/interactive/ 2012/sep/13/money-uk-multi-millionaires-regional-breakdown (accessed 25 May 2013).

23. Goretti Horgan, "Devolution, Direct Rule and Neo-Liberal Reconstruction in Northern Ireland," Critical Social Policy 26(3) (2006), pp. 656-666, at 658-659.

24. O'Hearn, "How has Peace Changed the Northern Irish Political Economy?," pp. 110-111.

25. Martin Wolf, "The Seeds of Its Own Destruction," Financial Times 8 March 2009.

26. David Harvey, A Brief History of Neoliberalism (Oxford University Press, 2005), pp. 16, 31 .

27. Ibid., p. 33.

28. Göran Therborn, "Class in the 21st Century," New Left Review 2(78) (November-December 2012), p. 13.

29. Peter Schwartz and Peter Leyden, "The Long Boom: A History of the Future," 1980-2020, Wired 5(7) (July 1997).

30. David McNally, Global Slump: The Economics and Politics of Crisis and Resistance (Oakland: PM Press, 2011), p. 15.

31. Jodi Dean, The Communist Horizon (London: Verso, 2013), p. 21; Mark Fisher, Capitalist Realism: Is There No Alternative? (Winchester: Zero Books, 2009), p. 78.

32. Colin Crouch, The Strange Non-Death of Neoliberalism (Cambridge: Polity, 2011), p. vii.

33. McNally, Global Slump, p.187.

34. Fisher, Capitalist Realism, p. 2.

35. David Stuckler and Sanjay Basu, The Body Economic: Why Austerity Kills (London: Allen Lane, 2013).

36. Derk Birrell, Direct Rule and the Governance of Northern Ireland (Manchester: Manchester University Press, 2009), p. 155; Sean Byrne, Economic Assistance and Conflict Transformation (London: Routledge, 2011), pp. 63-64.

37. Frank Gaffikin and Mike Morrissey, Northern Ireland: The Thatcher Years (London: Zed Books, 1990), p. 87.

38. John Nagle, "Potemkin Village: Neo-Liberalism and Peace-Building in Northern Ireland?," Ethnopolitics 8(2) (June 2009), p. 177.

39. Conor McCabe, The Double Transition, p. 12; John Nagle, "Nostrum or Palliative?," p. 223.

40. O'Hearn, "How has Peace Changed the Northern Irish Political Economy?," p. 108.

41. Nolan, Peace Monitoring Report, pp. 28-29.

42. Joseph Rowntree Foundation, Monitoring Poverty and Social Exclusion, p. 34.

43. Katy Hayward, "Negative Silence: The Unspoken Future of Northern Ireland," Nordic Irish Studies 11(2) (2012), pp. 21-38.

44. Brian Kelly, "Neoliberal Belfast: Disaster Ahead?," Irish Marxist Review 1(2) (2012), p. 45.

45. Brendan Murtagh and Peter Shirlow, "Devolution and the Politics of Development in Northern Ireland," Environment and Planning C: Government and Policy 30 (2012), p. 51; John Nagle, "The Repositioning of Irish Nationalism in Northern Ireland: An Examination of Consociationalism and Devolution in Identity Change," Ethnopolitics Papers 21 (November 2012), pp. 21-22.

46. John Nagle, "Potemkin Village," p. 177.

47. Goretti Horgan and Anne Marie Gray, "Devolution in Northern Ireland: A Lost Opportunity?," Critical Social Policy 32(2) (2012), p. 475.

48. Ibid.

49. Murtagh and Shirlow, "Devolution and the Politics of Development," p. 51.

50. O'Hearn, "How has Peace Changed the Northern Irish Political Economy?," p. 112.

51. Conor McCabe, Sins of the Father: Tracing the Decisions That Shaped the Irish Economy (Dublin: The History Press, 2011). 
52. Louise Armitstead, "Davos 2012: Ireland is the 'Poster Child' for Debt-Stricken Europe," Daily Telegraph 26 January 2013.

53. Jocelyn Evans and Jonathan Tonge, "Social Class and Party Choice in Northern Ireland's Ethnic Blocs," West European Politics 32(5) (September 2009).

54. Anthony McIntyre, Good Friday: The Death of Irish Republicanism (New York: Ausubo Press, 2008).

55. The Usual Suspects, directed by Bryan Singer (1995). The scene referred to can be viewed here: http://www.youtube.com/watch?v=KnGo6Qm0Wt8 (accessed 4 July 2013).

56. Harvey, A Brief History of Neoliberalism, p. 202. This strategy of erasure also represents a recurrent theme in Owen Jones's timely study Chavs: The Demonization of the Working Class (London: Verso, 2011), pp. 45-48, 248.

57. Jan Pakulski and Malcolm Waters, The Death of Class (London: Sage, 1996).

58. John McGarry and Brendan O'Leary, Explaining Northern Ireland: Broken Images (London: Blackwell, 1995), pp. 152, 154, 157, 162, 164, 167, 336-337.

59. Jim Smyth and Andreas Cebulla, "The Glaciar Moves? Economic Change and Class Structure," in Colin Coulter and Michael Murray, eds., Northern Ireland After the Troubles: A Society in Transition (Manchester: Manchester University Press, 2008); Colin Coulter, "The Absence of Class Politics in Northern Ireland," Capital and Class 69 (1999), pp. 77-100.

60. Mike Savage, Fiona Devine, Niall Cunningham, Mark Taylor, Yaojun Li, Johs Hjellbrekke, Brigitte Le Roux, Sam Friedman, and Andrew Miles, "A New Model of Social Class? Findings from the BBC's Great British Class Survey Experiment," Sociology 47(2) (2013), pp. 219-250.

61. Perhaps the most important exception to this rule is a recent major report on the future of Northern Irish schools that challenges the liberal orthodoxy that the segregation of children along ethno-religious lines represents the principal challenge to educationalists and foregrounds instead the massive disparity in the academic performance of children from different class backgrounds. Paul Connolly, Dawn Purvis, and P. J. O'Grady, Advancing Shared Education (Belfast, March 2013).

62. See http://www.ark.ac.uk/nilt/2012/Political_Attitudes/NIRELND2.html (accessed 4 July 2013).

63. The cartoon is second in the carousel of images collated here: http://www.irishtimes. com/blogs/gallery/2011/06/11/a-rogues-gallery-40-years-of-martyn-turner-cartoons/ (accessed 5 July 2013). 